\title{
CORRESPONDENCE
}

\section{Latent Hypothyroidism in Adults}

by Jeannine Schübel, PD Dr. med. Joachim Feldkamp, Prof. Dr. med. Antje Bergmann, Dr. med. Wolfgang Drossard, and Dr. rer. medic. Dipl.-Soz. Karen Voigt, MPH in issue 25/2017 in itself does not stimulate the growth of thyroid cells (1). The fear that a raised concentration of TSH triggers the development of goiter is therefore unwarranted and does not justify treatment with L-thyroxine.

TSH concentrations of patients being treated with lithium should be measured at regular intervals, in order to detect the possible death of thyroid cells. Therapy with L-thyroxine should then be initiated when the TSH concentration is $>10 \mathrm{mU} / \mathrm{L}$. Individually, and on the basis of a particular constellation of symptoms, for example, an attempt at initiating treatment can be considered in TSH concentrations $\geq 10 \mathrm{mU} / \mathrm{L}$. However, it should be borne in mind that it has not been proven that psychiatric symptoms improve as a result of treatment with L-thyroxine (2).

DOI: 10.3238/arztebl.2017.0752b

\section{REFERENCES}

1. Gärtner R, Dugrillon A: Vom Jodmangel zur Struma - Pathophysiologie der Jodmangelstruma. Internist 1998; 39: 566.

2. Reuters VS, Almeida CdP, Teixeira PdFdS, et al.: Effects of subclinica hypothyroidism treatment on psychiatric symptoms, muscular complaints, and quality of life. Arq Bras Endocrinol Metabol 2012; 56: $128-36$

3. Schübel J, Feldkamp J, Bergmann A, Drossard W, Voigt K: Latent hypothyroidism in adults. Dtsch Arztebl Int 2017; 114: 430-8.

\section{REFERENCES}

1. Schübel J, Feldkamp J, Bergmann A, Drossard W, Voigt K: Latent hypothyroidism in adults. Dtsch Arztebl Int 2017; 114: 430-8.

\section{Dr. med. Dirk Schmoll}

Psychiatrische Abteilung, Schlosspark-Klinik, Berlin Dirk.Schmoll@schlosspark-klinik.de

\section{Conflict of interest statement}

The author declares that no conflict of interest exists.

\section{In Reply:}

The development of goiter is triggered primarily by iodine deficiency. Thyroid-stimulating hormone (TSH)

\author{
On behalf of the authors \\ Jeannine Schübel \\ Dr. rer. medic. Dipl.-Soz. Karen Voigt, MPH \\ Medizinische Fakultät Carl Gustav Carus \\ der Technischen Universität Dresden \\ Bereich Allgemeinmedizin/MK3 \\ Jeannine.Schuebel@uniklinikum-dresden.de
}

\section{Conflict of interest statement}

Dr. Voigt, Jeannine Schübel and Prof. Bergmann are authors of the German College of General Practitioners and Family Physicians (DEGAM, Deutsche Gesellschaft für Allgemeinmedizin und Familienmedizin) guideline „Erhöhter TSH-Wert in der Hausarztpraxis [Raised TSH values in general practice]" (AWMF no. 053-046).

Jeannine Schübel receives royalties from Elsevier

\section{Erratum}

In the Clinical Snapshot entitled "A Rare Cause of Ileus in a Two-Year-Old Boy" by Johannes Leonhardt and Sylvia Glüer, the following sentence says erroneously: "Meckel's diverticulum, a remnant of the omphaloenteric duct of the embryo, has an incidence of approximately $2 \%$ of the population (ca. 8 of every 10000 persons), but only $4 \%$ of the affected persons develop symptoms." One the one hand, this clearly refers to the prevalence, rather than the incidence, of Meckel's diverticulum. On the other hand, the phrase in parentheses was put in the wrong place, which means that it refers to the wrong group of persons. The correct sentence should read: "Meckel's diverticulum, a remnant of the omphaloenteric duct of the embryo, has a prevalence of approximately $2 \%$ of the population, but only $4 \%$ of the affected persons (ca. 8 of every 10000 persons) develop symptoms." 